\title{
Research on the test of fatigue crack of Q420qE
}

\author{
Qiming $\mathrm{Yu}^{\mathrm{a}}$ Feng Zhou ${ }^{\mathrm{b}} \quad$ Zhi zhang ${ }^{\mathrm{a}}$ \\ ( ${ }^{a}$ Civil engineering and architectural institute, Wuhan Polytechnic University, Wuhan 430023, \\ Hubei ${ }^{b}$ East Lake Wuhan New Technology Development Zone CMC,430000, Hubei )
}

Keywords: Q420qE;base material;heat-affected zone;weld seam; Fatigue performance;

Abstract. This paper study the process and characteristics of the bridge structure steelQ420qE fatigue crack prefabricated. The results provide an experimental base and computing foundations for the bridge This paper studies the Crack tip opening displacement fatigue precracking experiment on steel Q420qE. The experiment respectively tested of Fatigue crack growth of base material, heat-affected zone, Weld seam, whose results are analyzed, and the corresponding conclusions were studied.

\section{Introduction}

The experiment respectively tested Fatigue crack growth of base material, heat-affected zone ,Weld seam of Q420qE, whose results are analyzed, and the corresponding conclusions are drawn..

\section{Test materials}

The using material --- Q420qE high-strength steel plate is produced by Wuhan iron and steel group. According to the British standard BS7448, prepare three points bending standard sample. Intercept 58mm test sample from bridge joist steel Q420qE. the gap direction is thickness direction, and then Register the number of the sample group.After finishing the front processing program, carefully buff the CTOD samples with sand paper with hand to make the surface more bright and smooth; Then clean the parts prepared to be cut and after that, confirm the position of the notch, mark the processing line according to British Code BS7448 and keep a record. Finally, process the CTOD samples by using cutting machine .After that, the precision should be high, the cutting surface should be smooth and almost no distortion. During the process, the plane of crack must be perpendicular to the surface of the sample and the deviation be controlled within $\pm 2^{0}$,the deteriorative layer can be slowly wiped away with sand paper because it's thin.

\section{Experimental method}

Throughout the whole experimental process, the fatigue crack of $2 \mathrm{~mm}$ can be obtained firstly with low stress ratio $\mathrm{R}=0.1$, then extends the crack to $5 \mathrm{~mm}$ (concrete length is based on the experiment) with higher stress ratio $\mathrm{R}=0.6$, and at the same time, make sure that the upper limit value of the maximum load of high frequency fatigue tester remains unchanged. Through this experimental method, it can be guaranteed that the crack tip stress will remain at low level and the evaluation result of fracture toughness CTOD will be more objective, true, and accurate. 


\section{Date process and results of fatigue crack experiments}

The fatigue crack growth situations of base material, heat-affected zone, Weld seam of Q420qE are shown in tab 1-1, tab 1-2, tab 1-3according to the date acquisition system record of fatigue experiment machine.

Tab 1-1 The fatigue crack growth of H58

\begin{tabular}{|c|c|c|c|c|c|c|}
\hline $\begin{array}{l}\text { specimen } \\
\text { number }\end{array}$ & $\begin{array}{l}\text { specimen } \\
\text { thickness } \\
(\mathrm{mm})\end{array}$ & $\begin{array}{l}\text { The } \\
\text { minimum } \\
\text { of the } \\
\text { fatigue } \\
\text { crack } \\
\text { growth } \\
\text { ( } \mathrm{mm})\end{array}$ & $\begin{array}{l}\text { The } \\
\text { maximum } \\
\text { of the } \\
\text { fatigue } \\
\text { crack } \\
\text { growth } \\
(\mathrm{mm})\end{array}$ & $\begin{array}{l}\text { The average } \\
\text { of the fatigue } \\
\text { crack growth } \\
(\mathrm{mm})\end{array}$ & $\begin{array}{l}\text { The cycle number } \\
\qquad \mathrm{N} \\
\left(10^{3}\right)\end{array}$ & $\begin{array}{c}\text { Frequency } \\
(\mathrm{Hz})\end{array}$ \\
\hline H58-1 & 52.00 & 4.990 & 5.070 & 5.060 & 21.3 & 110.5 \\
\hline H58-2 & 51.98 & 4.870 & 5.450 & 5.150 & 23.2 & 115.5 \\
\hline H58-3 & 51.98 & 4.010 & 5.650 & 5.160 & 22.5 & 115.3 \\
\hline H58-4 & 52.02 & 4.120 & 5.510 & 5.220 & 22.6 & 117.8 \\
\hline H58-5 & 52.02 & 4.060 & 5.210 & 5.120 & 21.4 & 115.6 \\
\hline H58-6 & 51.98 & 4.950 & 5.310 & 5.220 & 25.6 & 117.8 \\
\hline H58-7 & 52.01 & 4.740 & 5.710 & 5.170 & 22.9 & 113.4 \\
\hline H58-8 & 52.07 & 4.850 & 5.550 & 5.040 & 21.1 & 110.6 \\
\hline H58-9 & 52.01 & 4.970 & 5.400 & 5.210 & 22.9 & 115.7 \\
\hline H58-10 & 52.00 & 4.620 & 5.450 & 4.990 & 22.3 & 117.7 \\
\hline H58-11 & 52.01 & 4.790 & 5.110 & 5.010 & 21.3 & 108.0 \\
\hline H58-12 & 52.00 & 4.840 & 5.260 & 5.150 & 22.9 & 109.7 \\
\hline
\end{tabular}

Tab 1-2 The fatigue crack growth of H58W

\begin{tabular}{|l|l|l|l|l|l|l|}
\hline $\begin{array}{l}\text { specimen } \\
\text { number }\end{array}$ & $\begin{array}{l}\text { specimen } \\
\text { thickness } \\
(\mathrm{mm})\end{array}$ & $\begin{array}{l}\text { The minimum } \\
\text { of } \\
\text { fatigue crack } \\
\text { growth (mm) }\end{array}$ & $\begin{array}{l}\text { The } \\
\text { maximum of } \\
\text { the fatigue } \\
\text { crack growth } \\
\text { (mm) }\end{array}$ & $\begin{array}{l}\text { The average } \\
\text { of the fatigue } \\
\text { crack growth } \\
(\mathrm{mm})\end{array}$ & $\begin{array}{l}\text { The } \\
\text { cycle } \\
\text { number N }\end{array}$ & Frequency \\
\hline H58R-1 & 52.02 & 4.750 & 5.130 & 5.040 & 33.2 & 110.9 \\
\hline H58R-2 & 51.96 & 4.670 & 5.330 & 5.250 & 38.4 & 117.7 \\
\hline H58R-3 & 52.02 & 4.080 & 5.780 & 5.340 & 24.1 & 116.5 \\
\hline H58R-4 & 52.02 & 5.500 & 5.800 & 5.320 & 29.2 & 116.3 \\
\hline H58R-5 & 52.02 & 5.160 & 5.990 & 5.430 & 37.9 & 115.3 \\
\hline H58R-6 & 51.98 & 4.950 & 5.140 & 5.100 & 51.7 & 114.8 \\
\hline H58R-7 & 52.00 & 4.240 & 5.270 & 5.190 & 39.2 & 113.2 \\
\hline H58R-8 & 52.11 & 4.750 & 5.710 & 5.420 & 48.0 & 115.5 \\
\hline H58R-9 & 51.98 & 4.200 & 5.970 & 5.600 & 46.7 & 115.7 \\
\hline H58R-10 & 52.03 & 4.680 & 5.250 & 5.140 & 33 & 117.1 \\
\hline H58R-11 & 51.99 & 4.880 & 5.110 & 4.980 & 41.8 & 117.6 \\
\hline H58R-12 & 52.02 & 4.860 & 5.690 & 5.210 & 42.3 & 112.6 \\
\hline
\end{tabular}


Tab 1-3 The fatigue crack growth of H58W

\begin{tabular}{|c|c|c|c|c|c|c|}
\hline $\begin{array}{c}\text { specimen } \\
\text { number }\end{array}$ & specimen & $\begin{array}{c}\text { The } \\
\text { thinimum } \\
\text { of the } \\
\text { fatigue } \\
\text { crack } \\
\text { growth } \\
\text { (mm) }\end{array}$ & $\begin{array}{c}\text { The } \\
\text { maximum } \\
\text { of the } \\
\text { fatigue } \\
\text { crack } \\
\text { growth } \\
(\mathrm{mm})\end{array}$ & $\begin{array}{c}\text { The } \\
\text { average of } \\
\text { the fatigue } \\
\text { crack growth } \\
(\mathrm{mm})\end{array}$ & $\begin{array}{c}\text { The cycle } \\
\text { number N }\end{array}$ & Frequency \\
\hline H58W-1 & 52.00 & 4.680 & 5.370 & 5.140 & 77.2 & 109.8 \\
\hline H58W-2 & 52.02 & 4.880 & 5.240 & 5.050 & 60.4 & 115.7 \\
\hline H58W-3 & 52.01 & 4.830 & 6.020 & 5.160 & 82.3 & 117.5 \\
\hline H58W-4 & 51.89 & 4.850 & 5.210 & 5.020 & 70.8 & 116.7 \\
\hline H58W-5 & 52.04 & 4.970 & 5.210 & 5.130 & 71.5 & 117.3 \\
\hline H58W-6 & 51.91 & 4.650 & 5.220 & 5.160 & 81.8 & 117.3 \\
\hline H58W-7 & 52.06 & 4.500 & 5.060 & 4.990 & 77.1 & 113.2 \\
\hline H58W-8 & 52.08 & 5.020 & 5.260 & 5.220 & 68.5 & 117.7 \\
\hline H58W-9 & 51.98 & 4.900 & 5.750 & 5.670 & 77.6 & 110.4 \\
\hline H58W-10 & 52.06 & 4.510 & 5.020 & 4.940 & 68.4 & 109.3 \\
\hline H58W-11 & 52.04 & 4.630 & 5.120 & 4.980 & 75.1 & 104.9 \\
\hline H58W-12 & 51.96 & 4.680 & 5.630 & 5.240 & 85.7 & 112.3 \\
\hline
\end{tabular}

From table 1-1, 1-2,1-3 we can see that the same thickness of bridge steel Q420qE base metal, heat affected zone and weld zone fatigue crack growth, the ability to resist fatigue crack growth from big to small order is: weld, heat affected zone, base metal Q420qE. From the experimental results we can know that the material is different, and the anti fatigue performance is also very strong.

\section{Conclusion}

According to the test purpose and test the actual situation, in accordance with the metal material fracture toughness CTOD test specification, all specimens were fatigue pre crack, its purpose is in test chamber to get the real simulation of natural the sharp crack. The fatigue crack of all specimens was carried out at room temperature under the condition of normal temperature, and the crack propagation length and the number of cycles were obtained. the ability to resist fatigue crack growth from big to small order is: weld, heat affected zone, base metal Q420qE. From the experimental results we can know that the material is different, and the anti fatigue performance is also very strong.

\section{Acknowledgments}

This work was supported by the research project of Hubei Provincial Education Department(NO Q20151708)

\section{References}

[1] Sutton MA,Boone ML,Ma F,Helm JD.A combined modeling-experimental study of the crack opening displacement criterion for characterization of stable crack growth under mixed mode I/II loading in thin sheet materials. Engng Fract Mech 2000;66:171-85. 
[2] Qiming Yu, CTOD fracture toughness tests and numerical simulation for bridge steel Q420qE, ICMS2009

[3] Sutton MA,Deng X,Ma F,Newman Jr JC,James M.Development and application of a crack tip opening displacement-based mixed mode fracture criterion.Int J Solids Struct 2000;37:3591-618.

[4] Qiming Yu, CTOD fracture toughness tests and numerical simulation for welded joints of Q370qE, 28th International Conference on Ocean, 2009, Offshore and Arctic Engineering, Honolulu, Hawaii

[5] YuanQin Wang, Steel structure brittle failure analysis of the accident. Industrial building press, 1998, 28(5):55-58 